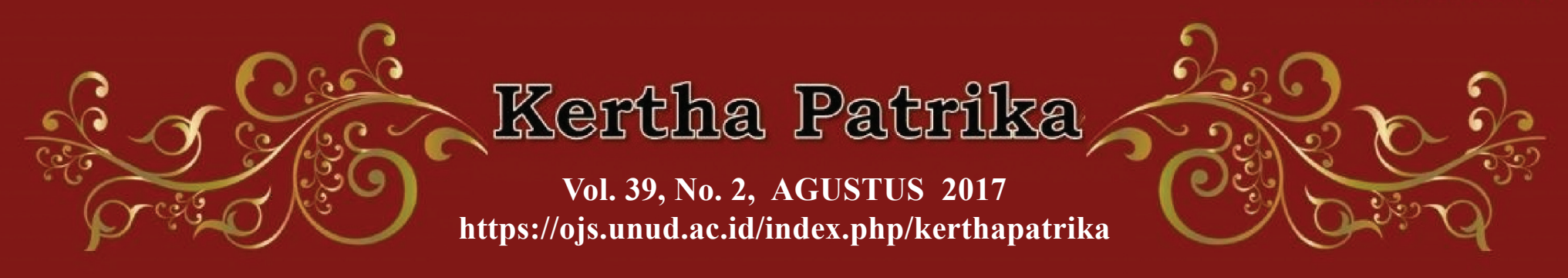

\title{
EKSISTENSI TANAH ADAT DI BALI DAN PROBLEMATIKA HUKUM DALAM PENGEMBANGAN INVESTASI
}

Oleh :

I Gusti Agung Mas Rwa Jayantiari ${ }^{1}$

Fakultas Hukum Universitas Udayana Denpasar

\begin{abstract}
Abstrak
Kebutuhan lahan untuk menunjang investasi pariwisata di Bali ternyata telah menyasar pada pemanfaatan tanah-tanah milik masyarakat adat. Artikel ini mengangkat isu mengenai pesatnya fenomena investasi di Bali yang selaras dengan kebijakan nasional di bidang penanaman modal serta adanya kebutuhan untuk perlindungan hukum bagi tanah-tanah milik masyarakat adat di Bali. Tulisan merupakan penelitian hukum normatif yang disusun dengan maksud untuk menyajikan kajian hukum terkait kasus-kasus tanah adat di Bali sebagai dampak dari aktivitas investasi. Dapat dikemukakan bahwasanya eksistensi tanah adat akan sangat dipengaruhi oleh penetapan kebijakan negara dalam investasi tataran norma dasar, regulasi nasional dan nasional, dan termasuk produk living law di Bali (awig-awig dan perarem). Dengan demikian, penentuan dapat atau tidaknya investasi dilakukan di wilayah desa adat ditentukan oleh hukum adatnya masing-masing yang tertuang di dalam awig-awig dan/atau perarem.
\end{abstract}

Kata Kunci: Tanah Adat, Investasi, Bali, Hukum Adat.

\section{Abstract}

The need for land to support tourism in Bali has turned out to have targeted the utilization of customary communities' lands. This article raises the issue of the rapid investment phenomenon in Bali in line with national policy in the field of investment and the need for customary communities' lands in Bali. The writing is a normative legal research that is aimed to discuss issues related to customary land cases in Bali as a result of investment activity. It can be argued that the existence of customary land will be highly upheld by the provisions of state laws and regulations, and includes living law products in Bali (awig-awig and perarem). Thus, the determination of whether the investment can be implemented or not in the customary village area is determined by the customary law of each village as stated in their awig-awig and lor perarem.

Keywords: Customary Lands, Investment, Bali, Customary Law.

DOI: https:doi.org/10.24843/KP.2017.v39.i02.p03

Copyright (C) 2017 Jurnal Kertha Patrika.

\section{Pendahuluan}

\subsection{Latar Belakang}

Industri pariwisata di Bali yang berkembang pesat ternyata membutuhkan lahan untuk dikembangkan. Faktanya, tingginya harga tanah di sejumlah kawasan destinasi wisata di Bali, khususnya di Bali Selatan, ${ }^{2}$ membuat pelaku investasi mencari alternatif baru dalam menanamkan

\footnotetext{
${ }^{1}$ I Gusti Agung Mas Rwa Jayantiari adalah Dosen Fakultas Hukum Universitas Udayana, Denpasar Bali, korespondensi dengan penulis melalui email : gungmasjayanti@yahoo.co.id

2 https://finance.detik.com/properti/2194947/harga-tanah-di-bali-naik-400-dalam-setahun.
} 
modalnya. Sejumlah investor telah mulai menginisiasi dan melaksanakan investasi di wilayah Utara, Timur, dan Barat Provinsi Bali sesuai dengan arah kebijakan pemerintah dalam rangka pemerataan ekonomi di Bali. Sebagai konsekuensinya, lahan-lahan masyarakat di ketiga wilayah tersebut mulai terdampak akibat pergerakan ekonomi. Menariknya, di antara lahan-lahan yang menjadi lokasi potensial untuk berinvestasi ternyata terdapat tanah-tanah milik masyarakat adat.

Situasi di mana keberadaan tanah-tanah adat beririsan dengan kepentingan penanaman modal memang merupakan isu yang penting untuk dikaji. Selama ini, praktik investasi yang dilakukan di tanah-tanah adat tidak sepenuhnya berlangsung lancar. Justru, konflik antara masyarakat adat dan para penanam modal cukup sering diberitakan di media yang menjadikan kesan bahwa investasi di tanah-tanah adat cukup problematik. ${ }^{3}$

Gencarnya investasi sesungguhnya merupakan kebijakan nasional peningkatan penanaman modal. Pemerintah dengan serius mereduksi hambatan-hambatan investasi termasuk di antaranya dengan cara menyederhanakan prosedur perizinan usaha dan debirokratisasi. ${ }^{4}$ Kebijakan tersebut ternyata berimbas kepada regulasi investasi di daerah-daerah, termasuk Bali. Pada tahun 2016, sejumlah 86 peraturan daerah dan peraturan bupati atau wali kota di Provinsi Bali telah dibatalkan, yang mana pencabutan peraturan-peraturan karena dianggap menghambat pengembangan investasi. ${ }^{5}$ Pembatalan tersebut didasarkan pada instruksi-instruksi Menteri Dalam Negeri mengenai Pencabutan atau Perubahan Perda, Peraturan Kepala Daerah, dan Keputusan Kepala Daerah yang menghambat birokrasi dan perizinan investasi. ${ }^{6}$

Pada titik ini, politik hukum berkaitan dengan isu investasi di satu sisi dan pertanahan di sisi lain menjadi perlu untuk dipahami dengan proporsi kepentingan yang seimbang. Politik pertanahan yang menjadi dasar untuk pencapaian tujuan pasal 33 ayat 3 UUD 45 tersebut secara umum ditujukan bagi tercapainya keadilan sosial bagi seluruh lapisan masyarakat untuk memperoleh sesuatu hak atas tanah dan mempunyai kesempatan yang sama untuk memperoleh bagian manfaat dari tanah bagi diri sendiri dan keluarganya. Secara khusus penjabaran politik pertanahan juga meliputi di antaranya melindungi hak perseorangan dan masyarakat hukum adat serta memberikan jaminan terhadap kepastian haknya. ${ }^{7}$

\subsection{Tujuan Penulisan}

Isu utama dalam artikel ini adalah pesatnya fenomena investasi di Bali yang selaras dengan kebijakan nasional di bidang penanaman modal serta adanya kebutuhan untuk perlindungan

3 Fakta dan analisis mengenai praktik investasi yang dilakukan di tanah-tanah adat dan konflik antara masyarakat adat dan para penanam modal akan dibahas pada bagian 2.1. dan 2.1 dari artikel ini.

4 http://www.hukumonline.com/berita/baca/lt51cd28c1f2efc/pemerintah-janji-sederhanakan-izin-investasi dan http:// kalimantan.bisnis.com/read/20170803/433/677414/penanaman-modal-daerah-diminta-sederhanakan-izin- .

5 http://regional.kompas.com/read/2016/06/17/17215281/86.peraturan.daerah.di.bali.dibatalkan.

6 Ibid. Instruksi Menteri Dalam Negeri Nomor 582/476/SJ Tanggal 16 Pebruari 2016 tentang Pencabutan atau Perubahan Perda, Peraturan Kepala Daerah dan Keputusan Kepala Daerah yang menghambat birokrasi dan izin investasi dan Instruksi Menteri Dalam Negeri Nomor 582/1107/SJ tanggal 4 April 2016 tentang Penegakan Instruksi Menteri Dalam Negri Nomor 182/1107/SJ tentang Pencabutan atau Perubahan Perda, Peraturan Kepala Daerah, dan Keputusan Kepala Daerah yang menghambat birokrasi dan perizinan investasi.

7 Maria SW Sumardjono, 2008, Tanah dalam Perspektif Hak Ekonomi, Sosial dan Budaya, Jakarta : Penerbit Kompas, h. 21. 
hukum bagi tanah-tanah milik masyarakat adat di Bali. Tulisan ini disusun untuk menyajikan kajian mengenai eksistensi tanah adat di bali dan problematika hukum dalam pengembangan investasi.

\subsection{Metode}

Tulisan ini merupakan penelitian hukum normatif yang mengkaji norma-norma yang tertuang di dalam peraturan perundang-undangan nasional dan lokal yang berkaitan dengan isu pertanahan, masyarakat hukum adat, dan penanaman modal. Analisis dilakukan dengan melakukan identifikasi dan menarik benang merah di antara fakta-fakta aktivitas investasi di tanah-tanah adat sebagaimana tersaji di dalam berbagai studi dan penelitian ilmiah serta sumber-sumber lainnya.

\section{HASIL DAN PEMBAHASAN}

\subsection{Kewenangan Pemerintah Daerah di Bidang Pertanahan (Adat) dan Investasi}

Adonia Ivonne Laturette melakukan studi tentang Kewenangan Pemerintah Daerah Terhadap Hak Ulayat Masyarakat Hukum Adat Setelah Berlakunya Undang-Undang Nomor 32 Tahun 2004. Dalam analisisnya dinyatakan bahwa undang-undang tersebut secara tegas mengatur tentang kewenangan pemerintah di bidang pertanahan sebagai pemerintahan wajib. Oleh karena Pemerintah daerah memiliki kewenangan mengatur masalah peruntukan dan penggunaan pertanahan di daerah maka tentunya termasuk di dalamnya kewenangan untuk mengatur tanahtanah ulayat masyarakat Hukum Adat. ${ }^{8}$ Saat ini, Undang-Undang Republik Indonesia Nomor 23 Tahun 2014 Tentang Pemerintahan Daerah menentukan bahwa bidang pertanahan dan penanaman modal merupakan Urusan Pemerintahan Wajib yang tidak berkaitan dengan Pelayanan Dasar. ${ }^{9}$

Berkaitan dengan penulisan artikel ini, terdapat dua sub urusan yang merupakan lingkup dari pembagian urusan pemerintahan konkuren antara pemerintah pusat dan daerah provinsi dan daerah kabupaten/kota di bidang pertanahan. ${ }^{10}$ Pertama berkenaan dengan Sub urusan ganti kerugian dan santunan tanah untuk pembangunan, dimana pemerintah pusat memiliki urusan penyelesaian masalah ganti kerugian dan santunan tanah untuk pembangunan oleh pemerintah pusat, pemerintah pusat memiliki urusan penyelesaian masalah ganti kerugian dan santunan tanah untuk pembangunan oleh pemerintah pusat, pemerintah daerah provinsi memiliki urusan penyelesaian masalah ganti kerugian dan santunan tanah untuk pembangunan oleh daerah provinsi, dan pemerintah daerah kabupaten/kota memiliki urusan memiliki urusan penyelesaian masalah ganti kerugian dan santunan tanah untuk pembangunan oleh daerah kabupaten/kota.

Kedua, dalam sub urusan tanah ulayat, penetapan tanah ulayat yang lokasinya dalam daerah provinsi merupakan urusan pemerintah daerah provinsi, sedangkan penetapan tanah

8 Adonia Ivonne Laturette, Kewenangan Pemerintah Daerah Terhadap Hak Ulayat Masyarakat Hukum Adat Setelah Berlakunya Undang-Undang Nomor 32 Tahun 2004, Jurnal Sasi Vol. 17 No. 3 Bulan Juli-September 2011, h.6. https://ejournal. unpatti.ac.id/ppr_iteminfo_lnk.php?id=102.

9 Pasal 12 ayat (2) huruf d dan huruf 1 Undang-Undang Republik Indonesia Nomor 23 Tahun 2014 Tentang Pemerintahan Daerah.

10 Lampiran Undang-Undang Republik Indonesia Nomor 23 Tahun 2014 Tentang Pemerintahan Daerah Pembagian Urusan Pemerintahan Konkuren Antara Pemerintah Pusat dan Daerah Provinsi dan Daerah Kabupaten/Kota, huruf J. 
ulayat yang lokasinya dalam daerah kabupaten/kota merupakan urusan pemerintah daerah kabupaten/kota. Adapun pemerintah pusat tidak memiliki urusan berkaitan dengan tanah ulayat.

Dengan demikian, berkaitan dengan kewenangan pemerintah daerah dalam penggunaan lahan milik masyarakat adat, pemerintah daerah provinsi setidaknya memiliki urusan sebagai berikut:

1. penyelesaian masalah ganti kerugian dan santunan tanah untuk pembangunan oleh daerah provinsi

2. penetapan tanah ulayat yang lokasinya dalam daerah provinsi merupakan urusan pemerintah daerah provinsi

Adapun pemerintah daerah kabupaten/kota, kewenangan yang dimilikinya sehubungan dengan penggunaan lahan milik masyarakat adat setidaknya memiliki urusan sebagai berikut:

1. pemerintah daerah kabupaten/kota memiliki urusan memiliki urusan penyelesaian masalah ganti kerugian dan santunan tanah untuk pembangunan oleh daerah kabupaten/kota

2. penetapan tanah ulayat yang lokasinya dalam daerah kabupaten/kota merupakan urusan pemerintah daerah kabupaten/kota

Di bidang investasi pemerintah daerah dapat melibatkan dan mendorong peran serta masyarakat dan sektor swasta dalam pembangunan daerah melalui memberikan insentif dan/ atau kemudahan kepada masyarakat dan/atau investor. ${ }^{11}$ Di Bali, pengaturan ini telah ditindaklanjuti melalui penerbitan Peraturan Daerah Provinsi Bali Nomor 1 Tahun 2016 Tentang Pemberian Insentif dan/atau Kemudahan Kepada Masyarakat dan/Atau Penanam Modal. Selain itu, Kepala daerah dengan persetujuan Dewan Perwakilan Rakyat Daerah dapat menerbitkan obligasi daerah untuk membiayai investasi yang menghasilkan penerimaan daerah setelah memperoleh pertimbangan dari Menteri Dalam Negeri dan persetujuan dari Menteri Keuangan. ${ }^{12}$ Bahkan pemerintah daerah juga dapat mengadakan kerja sama investasi yang didasarkan pada pertimbangan efisiensi dan efektivitas pelayanan publik serta saling menguntungkan dengan pihak ketiga dalam rangka meningkatkan kesejahteraan rakyat. ${ }^{13}$

Sesuai dengan Pembagian Urusan Pemerintahan Bidang Penanaman Modal, pemerintah daerah provinsi dan kabupaten/kota memiliki urusan yang telah ditentukan. Berkaitan dengan penulisan artikel ini, terdapat dua sub urusan yang menjadi urusan baik pemerintah daerah provinsi maupun kabupaten/kota yakni sub urusan pengembangan iklim Penanaman Modal khususnya pembuatan peta potensi investasi di daerah serta sub urusan pengendalian pelaksanaan penanaman modal. ${ }^{14}$

\footnotetext{
11 Pasal 278ayat (1) dan (2) Undang-Undang Republik Indonesia Nomor 23 Tahun 2014 Tentang Pemerintahan Daerah.

12 Pasal 300 ayat (2) Undang-Undang Republik Indonesia Nomor 23 Tahun 2014 Tentang Pemerintahan Daerah.

13 Pasal 366 (1) huruf c jo. Pasal 363 ayat (1) dan ayat (2) huruf b Undang-Undang Republik Indonesia Nomor 23 Tahun 2014 Tentang Pemerintahan Daerah.

14 Lampiran Undang-Undang Republik Indonesia Nomor 23 Tahun 2014 Tentang Pemerintahan Daerah Pembagian Urusan Pemerintahan Konkuren Antara Pemerintah Pusat dan Daerah Provinsi dan Daerah Kabupaten/Kota, huruf R.
} 
Berkaitan dengan pelaksanaan investasi kepariwisataan di wilayah (palemahan) desa pakraman, secara normatif masing-masing desa pakraman mempunyai kewenangan. ${ }^{15}$ Hal ini dapat dilihat di dalam Pasal 1 angka 4 Peraturan Daerah Provinsi Bali Nomor 3 Tahun 2001 tentang Desa Pakraman yang mendefinisikan desa pakraman sebagai berikut:

"Desa pakraman adalah kesatuan masyarakat hukum adat di Propinsi Bali yang mempunyai satu kesatuan tradisi dan tata krama pergaulan hidup masyarakat umat Hindu secara turun temurun dalam ikatan kahyangan tiga atau kahyangan desa yang mempunyai wilayah tertentu dan harta kekayaan sendiri serta berhak mengurus rumah tangganya sendiri." Selain itu desa pakraman mempunyai wewenang untuk turut serta menentukan setiap keputusan dalam pelaksanaan pembangunan yang ada di wilayahnya terutama yang berkaitan dengan Tri Hita Karana serta mempunyai kewenangan untuk melakukan perbuatan hukum di dalam dan di luar desa pakraman. ${ }^{16}$

\subsection{Tren dan Problematika Pemanfaatan Tanah Adat bagi Kepentingan Investasi di Indonesia}

Aliansi Masyarakat Adat Nusantara (AMAN) memandang bahwa Pemerintah tidak konsisten dengan UU Pokok Agraria yang berujung pada banyaknya konflik tanah adat. Sebagai contoh, kasus lahan komunitas masyarakat adat Cek Bocek yang diambilalih oleh perusahaan tambang Newmont dan konflik lahan komunitas adat Talonang dengan PT Pulau Sumbawa Agro yang mengambil alih lahan atas izin negara. Masyarakat adat tidak memiliki sertifikat tanah yang merupakan bukti kuat pemilikan tanah. ${ }^{17}$

Sekretaris II Dewan Adat Papua John NR. Gobay menyayangkan dampak investasi bagi tanah-tanah adat di Papua. Ia menyatakan bahwa banyak konflik tanah di Papua yang belum tuntas, pengambilan tanah milik masyarakat adat dengan cara-cara yang kurang baik. Ia menyerukan agar pemerintah melakukan mapping tanah adat yang berdasarkan pada mekanisme musyawarah adat guna menjamin kejelasan kepemilikan tanah. ${ }^{18}$

Penelitian yang dilakukan Jemmy Sondakh menemukan bahwa kewenangan dan hak masyarakat adat dalam investasi pertambangan belum diatur dengan tegas. Pada kenyataannya masyarakat adat masih termarjinalisasi dalam pembuatan kontrak dan penyelenggaraan penanaman modal di bidang pertambangan yang berujung pada resistensi masyarakat terhadap investasi. Selain itu, terdapat pula hambatan-hambatan yuridis berkaitan dengan kepastian hukum terkait dengan hak-hak masyarakat adat serta belum jelasnya mekanisme bagi hasil investasi. ${ }^{19}$

Dian Cahyaningrum meneliti pengambilalihan tanah adat dalam rangka investasi perkebunan negara di Kalimantan Barat dan Sumatera Barat. ${ }^{20}$ Ketiadaan sertifikat tanah adat dan belum

15 Dewa Nyoman Gede Suatmaja, Peranan Majelis Desa Pakraman Bali Dalam Pelaksanaan Investasi Kepariwisataan Di Wilayah Desa Pakraman, Jurnal Magister Hukum Udayana, Vol. 5, No. 2, Juli 2016, h.359.

16 Pasal 6 huruf b dan c Peraturan Daerah Propinsi Bali Nomor 3 Tahun 2001 tentang Desa Pakraman.

17 http://bali.bisnis.com/read/20160429/10/59136/konflik-tanah-adat-akibat-ketidaktegasan-pemda-tegakkan-aturan.

18 Tabloid Jubi, Ini dampak investasi tambang bagi masyarakat adat di Papua,15 November 2016, http://tabloidjubi. com/artikel-1679-ini-dampak-investasi-tambang-bagi-masyarakat-adat-di-papua.html.

19 Jemmy Sondakh, Bagi Hasil Investasi Sebagai Hak Masyarakat Adat Pada Wilayah Pertambangan Di Era Otonomi Daerah, Jurnal Hukum Unsrat, Vol. 23, No. 8, Januari 2017, h.44. https://media.neliti.com/media/publications/81213-ID-none.pdf

20 Dian Cahyaningrum, Pemanfaatan Tanah Adat Untuk Kepentingan Penanaman Modal di Bidang Perkebunan Negara Hukum, Vol. 3, No. 1, Juni 2012, https://jurnal.dpr.go.id/index.php/hukum/article/view/222/163 
adanya peraturan daerah yang mengukuhkan atau mengakui hak masyarakat adat atas tanahnya, menjadikan proses pengambilalihan tanah adat untuk perkebunan di Kalimantan Barat harus dilakukan melalui musyawarah mufakat, yang sayangnya belum berjalan dengan baik karena adanya sejumlah intrik yang merugikan masyarakat adat. ${ }^{21}$ Bahkan adakalanya tanah adat di wilayah tersebut diambil oleh aparat dan langsung diberikan kepada investor karena menganggap tanah tersebut merupakan tanah negara. ${ }^{22}$ Penelitian ini juga mengungkap sikap keberatan masyarakat adat di Sumatra Barat terhadap kegiatan usaha perkebunan di daerahnya sehubungan dengan pengambilalihan tanah adat dapat mengakibatkan hilangnya tanah adat karena perubahan status menjadi tanah Hak Guna Usaha (HGU) yang menjadi tanah negara jika jangka waktunya telah berakhir. $^{23}$

Di Sumatera Barat, peraturan daerah setempat memungkinkan investor untuk memanfaatkan tanah ulayat dengan mengikutsertakan penguasa dan pemilik tanah ulayat sepanjang terdapat kesepakatan dengan masyarakat adat yang bersangkutan sebagai pemegang saham, bagi hasil dan dengan cara lain dalam waktu yang telah ditentukan dalam perjanjian yang dibuat secara tertulis di hadapan Pejabat Pembuat Akta Tanah/Notaris. ${ }^{24}$ Adapun mengenai subjek hukumnya, peraturan daerah sebagaimana dimaksud mengafirmasi mekanisme pendaftaran tanah ulayat dengan status yang beragam untuk jenis tanah adat yang berbeda, yakni Hak Guna Usaha, Hak Pakai atau Hak Pengelolaan, status hak milik. ${ }^{25}$ Akademisi Universitas Andalas Kurniawarman menjelaskan bahwa tanah ulayat pada prinsipnya dapat menjadi objek investasi. Berdasarkan temuan lapangan di Sumatera Barat, banyak tersedia tanah ulayat nagari yang dimiliki oleh seluruh anak nagari dan kedudukannya secara hukum didelegasikan kepada pemerintah nagari serta lembaga adat yaitu Kerapatan Adat Nagari. Zainul Daulay juga menyatakan bahwa tanah ulayat sebenarnya tidak akan jadi kendala bagi investor jika statusnya jelas dan pemanfaatannya dalam penanaman modal. ${ }^{26}$

\subsection{Dinamika Pemanfaatan Tanah Adat di Bali}

Tanah adat di Bali dikenal sebagai tanah druwe desa pakraman (tanah milik desa adat menurut Hukum adat Bali. Istilah ini juga lazim dikualifikasikan sebagai tanah ulayat sebagai tanah bersama yang dikuasai dan dimiliki oleh desa adat secara komunal. ${ }^{27}$ Sebagaimana dikualifikasikan oleh Swastawa Dharmayuda, tanah adat di Bali dapat dibedakan ke dalam beberapa kategori yaitu Tanah Druwe Desa yang berupa Tanah Pasar, Tanah lapang, Tanah kuburan/ setra, Tanah Laba Pura sebagai tanah milik desa yang khusus dipergunakan untuk keperluan pura (tempat ibadah umat Hindu), Tanah Pekarangan Desa (PKD) sebagai tanah yang dikuasai

\footnotetext{
21 Ibid, h.33, 34, 37.

22 Ibid, h.33.

23 Ibid, h.35-37.

24 Pasal 10 Peraturan Daerah Provinsi Sumatera Barat Nomor 6 Tahun 2008 Tentang Tanah Ulayat dan Pemanfaatannya.

25 Pasal 8 Peraturan Daerah Provinsi Sumatera Barat Nomor 6 Tahun 2008 Tentang Tanah Ulayat dan Pemanfaatannya.

${ }^{26}$ Kabar24,IniPemicuSengketa TanahUlayatdiSumbar, 18April2017,http://kabar24.bisnis.com/read/20170418/78/646188/ ini-pemicu-sengketa-tanah-ulayat-di-sumbar.

27 I Gusti Agung Mas Rwa Jayantiari dan I Ketut Kasta Arya Wijaya Tinjauan Yuridis Pengaturan Tanah Druwe Desa di Bali (Aspek Hukum Perlindungan Masyarakat Adat Atas Tanah), Wicaksana- Jurnal Lingkungan \& Pembangunan, Vol. 1 No. 1, Juni 2017, h.37. https://ejournal.warmadewa.ac.id/index.php/wicaksana/article/download/279/215
} 
oleh desa yang diberikan kepada warga desa (Krama desa) untuk kebutuhan perumahan, dan Tanah Ayahan Desa (AyDs) sebagai tanah yang dikuasai desa yang penggarapannya diserahkan kepada masing-masing warga desa dengan hak untuk dinikmati dan diberikan kewajiban untuk memberikan ayahan baik berupa tenaga maupun materi kepada desa. ${ }^{28}$

Putu Tyo Maharyanto meneliti pelaksanaan konversi hak atas tanah bekas milik Adat di Kecamatan Tegallalang, Kabupaten Gianyar serta menganalisis manfaat dari konversi tersebut. ${ }^{29}$ Penelitian ini menyimpulkan bahwa pelaksanaan konversi tersebut sesuai dengan Peraturan Pemerintah Nomor 24 tahun 1997 tentang Pendaftaran tanah. Konversi ini juga sangat dirasakan manfaatnya oleh masyarakat, karena masyarakat secara sah memiliki tanda bukti kepemilikan tanah berupa sertifikat hak milik atas tanah.

Putu Karlina Oktaviani Kusuma Dewi menganalisis formulasi hukum pengaturan perlindungan tanah adat yang digunakan sebagai lokasi investasi di Desa Jimbaran, Kabupaten Badung, Bali. Dari penelitian yang dilakukannya, tanah-tanah adat yang dipergunakan sebagai lokasi investasi meliputi tanah laba pura dan tanah pekarangan desa. Mekanisme pengambilan keputusan telah sesuai dengan hukum adat yang berlaku yakni berdasarkan hasil rapat banjar, sehingga penggunaan tanah adat tersebut tidak dipermasalahkan oleh warga masyarakat. Fakta bahwa awig-awig setempat tidak mengatur penggunaan tanah adat sebagai lokasi investasi bukanlah penghambat dalam penetapan tanah adat sebagai lokasi investasi karena hasil paruman (rapat anggota) yang dituangkan ke dalam Akta Notaris antara Bendesa Adat dengan pelaku usaha wisata sudah menjadi pijakan hukum untuk melakukan investasi. ${ }^{30}$

Persoalan mengenai tidak dikualifikasikannya desa pakraman sebagai subyek hukum pertanahan memang telah lama menjadi dilema bagi masyarakat ada di Bali. Situasi yang menempatkan desa pakraman bukan sebagai subjek hukum yang dapat mempunyai hak milik atas tanah menjadikan desa pakraman tidak dapat mendaftarkan hak miliknya ke Kantor Pertanahan Kabupaten/Kota) untuk mendapatkan sertipikat. Akibatnya, status kepemilikan tanah druwe desa pakraman di Bali menjadi mengambang. ${ }^{31}$ Mekanisme yang selama ini dipraktikkan adalah tanah milik masyarakat hukum adat dilepaskan dengan cara tukar guling (ruislag) atau melalui pelepasan hak atas tanah tersebut terlebih dahulu oleh kepala adat. ${ }^{32}$ Dalam perkembangannya, tanah adat telah diberikan status hak komunal berdasarkan Peraturan Menteri Agraria dan Tata Ruang /Kepala Badan Pertanahan Nasional Nomor 10 Tahun 2016 Tentang Tata Cara Penetapan Hak Komunal Atas Tanah Masyarakat Hukum Adat dan Masyarakat yang

\footnotetext{
28 Ibid, h.38.

29 Putu Tyo Maharyanto, Pelaksanaan Konversi Tanah Bekas Milik Adat Di Kecamatan Tegallalang Berdasarkan Peraturan Pemerintah Nomor 24 Tahun 1997, Jurnal Prasada, Vol. 4, No. 1, Maret 2017, h.66. https://ejournal.warmadewa.ac.id/index.php/ prasada/article/download/160/141

30 Putu Karlina Oktaviani Kusuma Dewi, 2016, Pengaturan Perlindungan Hukum Terhadap Tanah Adat Sebagai Lokasi Investasi Pariwisata, Tesis, Program Studi Magister Kenotariatan, Program Pascasarjana Universitas Udayana, Denpasar, https:// sinta.unud.ac.id/uploads/wisuda/1292461026-1-HAL\%20DEPAN.pdf

31 Dewa Ayu Oka Aspriani, A. Rachmad Budiono, I Nyoman Sirtha, Status Kepemilikan Tanah. Druwe Desa di Bali, http://download.portalgaruda.org/article.php?article=188328\&val=6466\&title=STATUS\%20KEPEMILIKAN\%20TANAH $\% 20$ \%20DRUWE\%20\%20DESA\%20DI\%20\%20BALI.

32 Hukumonline, Klinik, Cara Penyertifikatan Tanah Adat, 3 Juni 2014, http://www.hukumonline.com/klinik/detail/ 1t537ac3b737835/cara-penyertifikatan-tanah-adat.
} 
KERTHA PATRIKA

Volume 39, Nomor 2, Agustus 2017

Berada Dalam Kawasan Tertentu. Pasal 3 ayat (2) peraturan itu menyatakan bahwa masyarakat hukum adat dapat diberikan subjek hak komunal sepanjang memenuhi persyaratan sebagai berikut: ${ }^{33}$

1. Masyarakat adat masih dalam bentuk paguyuban;

2. Ada kelembagaan dalam perangkat penguasa adatnya;

3. Ada wilayah hukum adat yang jelas; dan

4. Ada pranata dan perangkat hukum, yang masih ditaati.

Ratna Artha Windari mengemukakan adanya dilema hukum dalam proses sertifikasi tanah AyDs di Bali ketika melakukan studi kasus terhadap konflik terkait tanah jenis tersebut di Desa Adat Panglipuran, Kabupaten Bangli. Perselisihan yang terjadi sesungguhnya bersifat internal di antara anggota masyarakat adat. Sebagian warga menghendaki agar dilakukan sertifikasi terhadap tanah adat sebagai bukti otentik kepemilikan atas tanah untuk menghindari terjadinya sengketa tanah di kemudian hari, sedangkan sebagian warga lainnya berpendapat sebaliknya karena menghendaki status sebagaimana sediakala untuk mempertahankan keutuhan dan integritas desa adat sebagai pengatur utama tanah ayahan desa. ${ }^{34}$ Kalangan yang menolak sertifikasi berasumsi dan mengkhawatirkan bahwa sertifikat akan menjadi dasar hukum untuk melakukan perjanjian dengan pihak ketiga, khususnya para investor yang berkeinginan untuk mendirikan villa di Desa Adat Panglipuran yang sekaligus juga merupakan desa wisata yang banyak dikunjungi baik oleh wisatawan domestik dan mancanegara. ${ }^{35}$ Secara arif, masyarakat adat setempat memutuskan bahwa perselisihan pertanahan, khususnya tanah ayahan desa dan tanah pekarangan desa, akan diselesaikan secara kekeluargaan terlebih dahulu sebelum diajukan ke desa adat Panglipuran. ${ }^{36}$

Ada pula studi yang dilakukan Astiti, Atu Dewi dan Faure yang menganalisis masuknya pariwisata ke Desa Tenganan, suatu desa tradisional di Kabupaten Karangasem-Bali yang dikenal secara turun-temurun memegang teguh adat istiadatnya. Studi tersebut menyimpulkan bahwa kendatipun aktivitas pariwisata telah menyentuh aspek kehidupan masyarakatnya, namun awigawig (hukum adat) yang berlaku bagi masyarakat adatnya melarang dilakukannya penjualan tanah bagi orang luar yang bukan anggota masyarakat Desa Tenganan. ${ }^{37}$

Sertifikasi tanah loloan (muara sungai) Tukad Yeh Poh merupakan salah satu kasus tanah yang timbul berkaitan dengan pengembangan pariwisata. Kasus ini cukup kompleks karena

33 Pasal 2 ayat (1), 3 ayat (1) , 4 ayat (1) Peraturan Menteri Agraria dan Tata Ruang /Kepala Badan Pertanahan Nasional Nomor 10 Tahun 2016 Tentang Tata Cara Penetapan Hak Komunal Atas Tanah Masyarakat Hukum Adat dan Masyarakat yang Berada Dalam Kawasan Tertentu.

34 Ratna Artha Windari, Dilema Hukum Penyertifikatan Tanah Ayahan Desa di Bali (Studi Kasus Konflik Adat Tanah Ayahan Desa di Desa Adat Panglipuran), Jurnal IKA Vol 8, No 2 (2010), h.210. https://ejournal.undiksha.ac.id/index.php/IKA/article/ download/167/158 .

35 Ibid.

36 Ibid, h.217.

37 Tjokorda Istri Putra Astiti, Anak Agung Istri Ari Atu Dewi, and Michael Faure, Tourism Development And Customary Land Law In Bali: The Case of the Tenganan Pagringsingan Village, Southwestern Journal of International Law, Volume 20 (2013), H. 139-140 http://heinonline.org/HOL/LandingPage?handle=hein.journals/sjlta20\&div=7\&id=\&page= . 
melibatkan pihak desa adat dan pengusaha. Bahkan eskalasi kasus tersebut telah mendapat perhatian dari berbagai pihak, termasuk Bupati Badung dan Kepala Kepolisian Daerah Bali. Kasus tersebut melibatkan desa adat yang mana warganya merasa keberatan atas rencana sebuah perusahaan yakni PT. Bali Unicom untuk membangun sarana pariwisata di wilayah tersebut. PT Bali Unicom telah mengantongi ijin Hak Guna Bangunan ( HGB) di Daerah Aliran Sungai (DAS) yang selama ini oleh masyarakat adat dijadikan kawasan yang dilestarikan dan disucikan. Hal yang menjadi pegangan bagi warga setempat adalah Keputusan Bupati Badung No. 637 tahun 2003 tentang Rencana Detail Tata Ruang Kecamatan Kuta Utara dimana kawasan yang selama ini menjadi wilayah Banjar Tegal Gundul tersebut tetap dibiarkan sebagai kawasan bebas. ${ }^{38}$

Dari pendekatan kelembagaan, perlu kiranya dikemukaan eksistensi Majelis Desa Pakraman (MDP) sebagai lembaga adat di Bali yang dibentuk melalui Peraturan Daerah Propinsi Bali Nomor 3 Tahun 2001 tentang Desa Pakraman. Lembaga ini memiliki sejumlah tugas, di antaranya untuk mengayomi adat istiadat; memberikan saran, usul dan pendapat kepada berbagai pihak baik perorangan, kelompok/ lembaga termasuk pemerintah tentang masalah-masalah adat. ${ }^{39}$ Lembaga ini juga berwenang untuk memusyawarahkan berbagai hal yang menyangkut masalah-masalah adat dan agama untuk kepentingan desa pakraman dan sebagai penengah dalam kasus-kasus adat yang tidak dapat diselesaikan pada tingkat desa. ${ }^{40}$ Berkaitan dengan pelaksanaan investasi di wilayah desa pakraman, MDP Bali telah mengeluarkan Keputusan MDP Bali Nomor 050/ Kep/Psm-1/MDP Bali/III/2006 yang menyatakan sebagai berikut: ${ }^{41}$

1. Setiap investasi di wewidangan/wawengkon (wilayah) desa pakraman patut mendapat rekomendasi desa pakraman, selain persetujuan dari instansi terkait lainnya.

2. Rekomendasi diberikan oleh bendesa berdasarkan keputusan paruman krama desa pakraman.

Dewa Nyoman Gede Suatmaja menyatakan bahwa MDP Bali memiliki peran yang relatif terbatas di dalam implementasi penanaman modal di bidang kepariwisataan di Bali. Peran tersebut dapat berupa memberikan saran, usul, dan pendapat yang tidak bersifat mengikat kepada para pihak yang berkepentingan (desa pakraman, investor, pemerintah) serta menjadi penengah (mediator) dalam hal penyelesaian konflik di bidang investasi kepariwisataan, khususnya yang dilakukan di wilayah desa pakraman. ${ }^{42}$

Cukup terlihat jelas bahwa terdapat otonomi dari masyarakat adat di Bali dalam penentuan investasi di wedidangan (wilayahnya) sebagaimana tercermin dari hukum adatnya masingmasing. Setidaknya dua studi yang dikutip di atas mengindikasikan bahwa dapat atau tidaknya

38 https://ramadhanadi.wordpress.com/2013/11/29/analisis-permasalahan-hukum-adat-kasus-loloan-yeh-poh-di-banjartegal-gundul-desa-adat-canggu-kuta-utara/, http://www.baliprov.go.id/Gubernur-Dukung-Upaya-Bupati-Badung-Amankan-Lolohan-Yeh-Poh, http://news.detik.com/berita/765130/dprd-bali-desak-proyek-discovery-suites-dihentikan, http://www.kabarnusa. com/2014/04/disesalkan-pengambilalihan-paksa-hotel.html\#.

39 Pasal 16 (1) huruf a dan b Peraturan Daerah Propinsi Bali Nomor 3 Tahun 2001 tentang Desa Pakraman.

40 Dewa Nyoman Gede Suatmaja, Op.Cit, h.362..

41 Dewa Nyoman Gede Suatmaja, Peranan Majelis Desa Pakraman Bali Dalam Pelaksanaan Investasi. Kepariwisataan Di Wilayah Desa Pakraman, Jurnal Magister Hukum Udayana, Vol. 5, No. 2, Juli 2016, h.362.

42 Ibid. 
aktivitas penanaman modal untuk dilakukan di wewidangan desa pakraman akan ditentukan oleh masing-masing desa pakraman melalui awig-awig dan/atau peraremnya masing-masing. Perlu juga diberikan catatan bahwasanya Keputusan MDP Bali Nomor 050/Kep/Psm-1/MDP Bali/III/2006 turut andil dalam memberikan pedoman dalam pelaksanaan investasi di wilayah desa pakraman yang justru semakin memperkuat kedudukan desa pakraman.

\section{PENUTUP}

Artikel ini menyajikan menyajikan kajian mengenai eksistensi tanah adat di bali dan problematika hukum dalam pengembangan investasi. Dari pembahasan dapat dicermati antara ko-eksistensi antara di satu sisi fenomena dan kebijakan investasi serta di sisi lain upaya perlindungan tanah milik masyarakat adat. Dapat dikemukakan bahwasanya eksistensi tanah adat akan sangat dipengaruhi oleh penetapan kebijakan negara dalam investasi baik dari tataran norma dasar, regulasi nasional dan nasional, dan termasuk produk living law di Bali (awig-awig dan perarem). Di Bali, tanah milik desa adat menurut Hukum Adat Bali dikenal sebagai tanah druwe desa pakraman sebagai tanah bersama yang dikuasai dan dimiliki oleh desa adat secara komunal. Dinamika yang berkembang di Bali berkaitan dengan isu investasi menunjukkan bahwa otonomi dari masyarakat adat di Bali dalam penentuan investasi di wedidangan (wilayahnya) tercermin dari hukum adatnya masing-masing. Sehingga, dapat atau tidaknya aktivitas penanaman modal untuk dilakukan di wilayah desa pakraman akan ditentukan oleh keputusan adat yang tertuang di dalam masing-masing awig-awig dan/atau perarem. Dari pendekatan kelembagaan, Majelis Desa Pakraman (MDP) ternyata memiliki peran sentral dalam memperkuat kedudukan masyarakat hukum adat di Bali dalam menghadapi fenomena investasi pelaksanaan investasi di wilayah desa pakraman. Salah satu keputusan MDP menentukan bahwa setiap investasi di wilayah desa pakraman patut mendapat rekomendasi dari desa pakraman yang disampaikan oleh bendesa (kepala desa adat) berdasarkan keputusan paruman krama desa pakraman (musyawarah anggota desa adat), selain persetujuan dari instansi terkait lainnya.

\section{DAFTAR PUSTAKA}

\section{A. Buku}

Maria SW Sumardjono, 2008, Tanah dalam Perspektif Hak Ekonomi, Sosial dan Budaya, Kompas, Jakarta.

\section{B. Jurnal}

Astiti, Tjokorda Istri Putra, Dewi, Anak Agung Istri Ari Atu And Faure, Michael, Tourism Development And Customary Land Law In Bali: The Case of the Tenganan Pagringsingan Village, Southwestern Journal of International Law, Volume 20, 2013.

Cahyaningrum, Dian, Pemanfaatan Tanah Adat Untuk Kepentingan Penanaman Modal di Bidang Perkebunan, Jurnal Negara Hukum, Vol. 3, No. 1, Juni 2012. 
Jayantiari, I Gusti Agung Mas Rwa dan Wijaya, I Ketut Kasta Arya, Tinjauan Yuridis Pengaturan Tanah Druwe Desa di Bali (Aspek Hukum Perlindungan Masyarakat Adat Atas Tanah), Wicaksana Jurnal Lingkungan \& Pembangunan, Vol. 1 No. 1, Juni 2017, h.37.

Laturette, Adonia Ivonne, Kewenangan Pemerintah Daerah Terhadap Hak Ulayat Masyarakat Hukum Adat Setelah Berlakunya Undang-Undang Nomor 32 Tahun 2004, Jurnal Sasi Vol. 17 No. 3 Bulan Juli-September 2011.

Maharyanto, Putu Tyo, Pelaksanaan Konversi Tanah Bekas Milik Adat Di Kecamatan Tegallalang Berdasarkan Peraturan Pemerintah Nomor 24 Tahun 1997, Jurnal Prasada, Vol. 4, No. 1, Maret 2017.

Suatmaja, Dewa Nyoman Gede, Peranan Majelis Desa Pakraman Bali Dalam Pelaksanaan Investasi Kepariwisataan Di Wilayah Desa Pakraman, Jurnal Magister Hukum Udayana, Vol. 5, No. 2, Juli 2016.

Sondakh, Jemmy, Bagi Hasil Investasi Sebagai Hak Masyarakat Adat Pada Wilayah Pertambangan Di Era Otonomi Daerah, Jurnal Hukum Unsrat, Vol. 23, No. 8, Januari 2017.

Suatmaja, Dewa Nyoman Gede, Peranan Majelis Desa Pakraman Bali Dalam Pelaksanaan Investasi. Kepariwisataan Di Wilayah Desa Pakraman, Jurnal Magister Hukum Udayana, Vol. 5, No. 2 , Juli 2016.

Windari, Ratna Artha, Dilema Hukum Penyertifikatan Tanah Ayahan Desa Di Bali (Studi Kasus Konflik Adat Tanah Ayahan Desa di Desa Adat Panglipuran), Jurnal IKA Vol 8, No 2, 2010.

\section{Tesis}

Putu Karlina Oktaviani Kusuma Dewi, 2016, Pengaturan Perlindungan Hukum Terhadap Tanah Adat Sebagai Lokasi Investasi Pariwisata, Tesis, Program Studi Magister Kenotariatan, Program Pascasarjana Universitas Udayana, Denpasar,

\section{Internet}

https://finance.detik.com/properti/2194947/harga-tanah-di-bali-naik-400-dalam-setahun.

http://www.hukumonline.com/berita/baca/lt51cd28c1f2efc/pemerintah-janji-sederhanakan-izin-investasi http://kalimantan.bisnis.com/read/20170803/433/677414/penanaman-modal-daerah-diminta-sederhanakan-izin-.

http://regional.kompas.com/read/2016/06/17/17215281/86.peraturan.daerah.di.bali.dibatalkan.

http://bali.bisnis.com/read/20160429/10/59136/konflik-tanah-adat-akibat-ketidaktegasan-pemda-tegakkan-aturan.

http://tabloidjubi.com/artikel-1679-ini-dampak-investasi-tambang-bagi-masyarakat-adat-di-papua.html. http://kabar24.bisnis.com/read/20170418/78/646188/ini-pemicu-sengketa-tanah-ulayat-disumbar. http://www.hukumonline.com/klinik/detail/lt537ac3b737835/cara-penyertifikatan-tanah-adat. 


\section{KERTHA PATRIKA}

Volume 39, Nomor 2, Agustus 2017

http://download.portalgaruda.org/article.php?article $=188328 \&$ val $=6466 \&$ title $=$ STATUS $\% 20$ KEPEMILIKAN\%20TANAH\%20\%20DRUWE\%20\%20DESA\%20DI\%20\%20BALI.

https://ramadhanadi.wordpress.com/2013/11/29/analisis-permasalahan-hukum-adat-kasus-loloanyeh-poh-di-banjar-tegal-gundul-desa-adat-canggu-kuta-utara/.

http://www.baliprov.go.id/Gubernur-Dukung-Upaya-Bupati-Badung-Amankan-Lolohan-Yeh-Poh.

http://news.detik.com/berita/765130/dprd-bali-desak-proyek-discovery-suites-dihentikan.

http://www.kabarnusa.com/2014/04/disesalkan-pengambilalihan-paksa-hotel.html\#.

\section{E. Peraturan Perundang-Undangan}

Undang-Undang Republik Indonesia Nomor 23 Tahun 2014 Tentang Pemerintahan Daerah, Lembaran Negara Republik Indonesia Tahun 2014 Nomor 244, Tambahan Lembar Negara Republik Indonesia Nomor 5587.

Peraturan Menteri Agraria dan Tata Ruang /Kepala Badan Pertanahan Nasional Nomor 10 Tahun 2016 Tentang Tata Cara Penetapan Hak Komunal Atas Tanah Masyarakat Hukum Adat dan Masyarakat yang Berada Dalam Kawasan Tertentu.

Instruksi Menteri Dalam Negeri Nomor 582/476/SJ Tanggal 16 Pebruari 2016 tentang Pencabutan atau Perubahan Perda, Peraturan Kepala Daerah dan Keputusan Kepala Daerah yang menghambat birokrasi dan izin investasi.

Instruksi Menteri Dalam Negeri Nomor 582/1107/SJ tanggal 4 April 2016 tentang Penegakan Instruksi Menteri Dalam Negri Nomor 182/1107/SJ tentang Pencabutan atau Perubahan Perda, Peraturan Kepala Daerah, dan Keputusan Kepala Daerah yang menghambat birokrasi dan perizinan investasi.

Peraturan Daerah Provinsi Sumatera Barat Nomor 6 Tahun 2008 Tentang Tanah Ulayat dan Pemanfaatannya, Lembaran Daerah Provinsi Suatera Barat Tahun 2008 Nomor 6.

Peraturan Daerah Propinsi Bali Nomor 3 Tahun 2001 tentang Desa Pakraman, Lembaran Daerah Provinsi Bali Tahun 2001 Nomor 29 Seri D Nomor 29. 